\title{
SUPPLEMENT TO THE PAPER “GROUNDWATER DYNAMICS BETWEEN PLANINSKO POLJE AND SPRINGS OF THE LJUBLJANICA RIVER, SLOVENIA" FROM BLATNIK ET AL. (2019) PUBLISHED IN ACTA CARSOLOGICA 48/2
}

\author{
DODATEK K ČLANKU »DINAMIKA PODZEMNE VODE MED \\ PLANINSKIM POLJEM IN IZVIRI LJUBLJANICE, SLOVENIJA" \\ OBJAVLJENEM V ACTA CARSOLOGICA 48/2
}

\author{
Matej BLATNIK ${ }^{1,2}$, Cyril MAYAUD ${ }^{1,2} \&$ Franci GABROVŠEK ${ }^{1,2, *}$
}

UDC 551.444(497.4)

\section{INTRODUCTION}

The article of Blatnik et al. (2019) "Groundwater dynamics between Planinsko Polje and springs of the Ljubljanica River, Slovenia" published in Acta Carsologica, 48/2 focused on describing the hydrogeological behaviour of the aquifer between Planinsko Polje and the springs of the Ljubljanica River. The authors analysed the effect of different high water events that occurred between January 2015 and May 2018. Interpretations were based on hydrographs obtained by continuous measurements of water level, temperature and specific electric conductivity in selected ponors, springs and water active caves located in the area between Planinsko Polje and the springs of the Ljubljanica River. Through these interpretations, different conceptual hydrological models about the dynamics and directions of the flow in the aquifer have been proposed and tested. A flow connection was proposed between the Hrušica Plateau, estavelles located at the NW border of Planinsko Polje, and caves Gradišnica (W2) and Gašpinova Jama (W3) close to town Logatec. In this supplement we provide new data recorded during unusual hydrological event in August 2018. These further support and stress the importance of connection between the Hrušica Plateau and Logatec region (W2 and W3).

\section{THE EVENT OF AUGUST 2018}

Between the $23^{\text {rd }}$ and the $26^{\text {th }}$ August 2018, an important rainfall event occurred above the recharge area of the Ljubljanica River. The total amount of rain varied greatly from one location to the other, with cumulative rainfall rates switching from $60 \mathrm{~mm}$ to $173 \mathrm{~mm}$ within a few kilometres distance (Fig. 1). While most of the area

${ }^{1}$ ZRC SAZU, Karst Research Institute, Titov trg 2, 6230 Postojna, Slovenia; e-mail: matej.blatnik@zrc-sazu.si, cyril.mayaud@zrcsazu.si, gabrovsek@zrc-sazu.si,

${ }^{2}$ UNESCO Chair on Karst Education, University of Nova Gorica, Glavni trg 8, 5271 Vipava, Slovenia

* Corresponding author 
southern from Planinsko Polje registered a total rainfall amount between 60 and $80 \mathrm{~mm}$ (Fig. 1), the area around the Hrušica Plateau recorded cumulative rainfall rate between 150 and $173 \mathrm{~mm}$, with the majority of the rain falling within a 13 hours period on the $25^{\text {th }}$ of August. This is especially visible at the meteorological stations Vodice, Logatec and Vrhnika, which respectively measured a total rainfall amount of 93, 114 and $124 \mathrm{~mm}$ for this day (ARSO 2020a).

The uneven spatial distribution of the rain resulted in different hydrological reactions within the entire Ljubljanica River recharge area (Fig. 2). As an example, the discharge of the Ljubljanica River increased rapidly from $2.5 \mathrm{~m}^{3} / \mathrm{s}$ to $71 \mathrm{~m}^{3} / \mathrm{s}$, and reached peak flow on August $26^{\text {th }}$ at 6:00. Conversely, the Unica River started to react half a day later due to the lower quantity of precipitation in southern part of the recharge area. The discharge recorded at the gauging station of Planinsko Polje slightly increased from a base flow value of $2.6 \mathrm{~m}^{3} / \mathrm{s}$ to a maximum of $11.1 \mathrm{~m}^{3} / \mathrm{s}$ on August 27 th at 15:30.

On Planinsko Polje the Unica River was entirely drained by the eastern line of ponors and did not reach the northern ponor area. Accordingly, the water level response in caves connected to the drainage from Planinsko Polje was small. The cave Vetrovna Jama pri Laški Kukavi (E2) registered a $1.7 \mathrm{~m}$ high increase of water level on August $26^{\text {th }}$ at $4: 00$, prior to the increase of the Unica River discharge. Then, the level oscillated around $0.8 \mathrm{~m}$ and stayed stable at $1 \mathrm{~m}$ also after the discharge of Unica River increased. In Najdena Jama (W1) the level increased for $1.2 \mathrm{~m}$ and stayed stable during the whole period.

Due to the high amount of rainfall in the Hrušica Plateau, the hydrological response observed in the caves located on its eastern border was significantly different (Fig. 2). The water level increased for $37 \mathrm{~m}$ in the cave

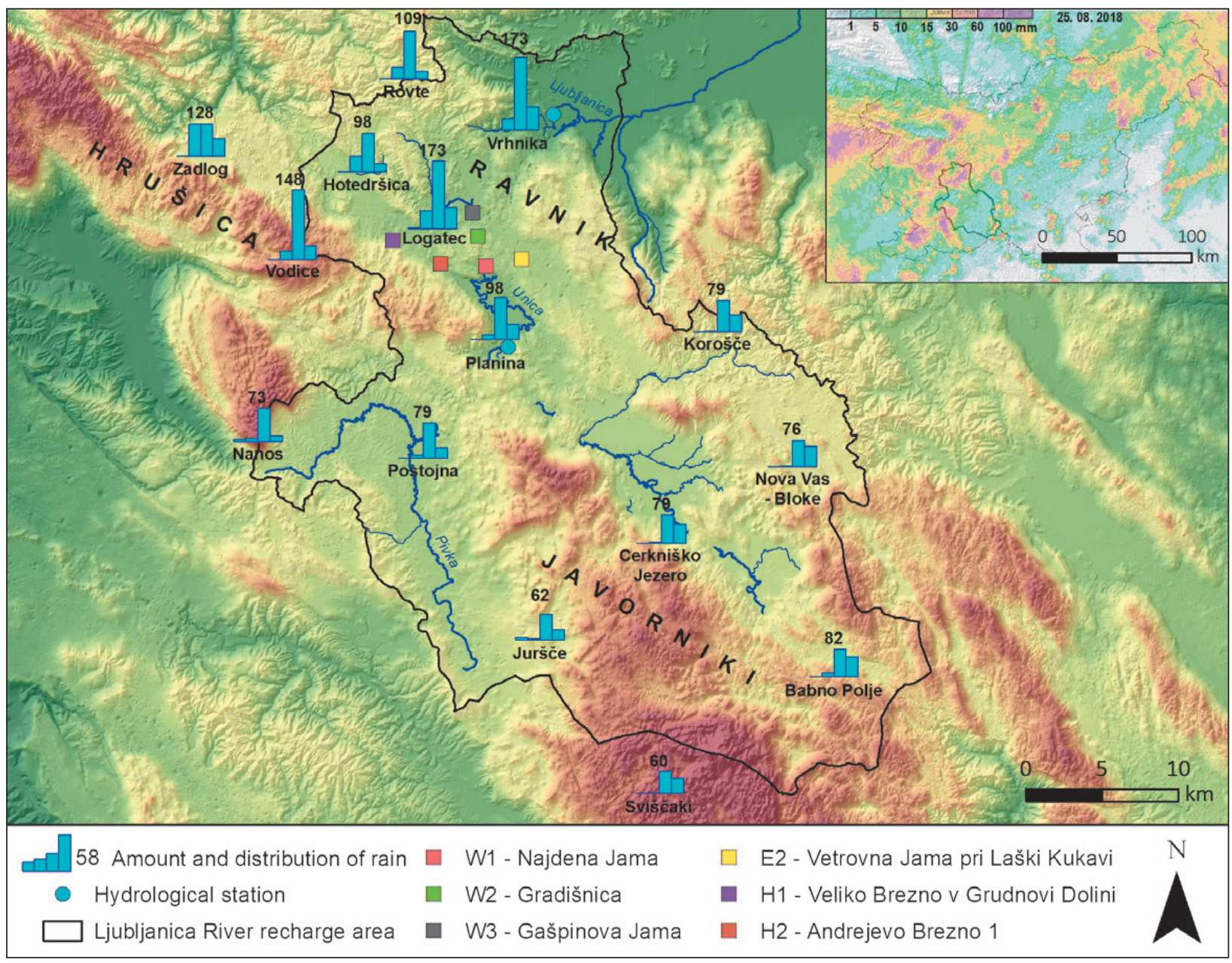

Fig. 1: Distribution and total amount of rainfall recorded between the $23^{\text {rd }}$ and the $26^{\text {th }}$ of August 2018 in the Ljubljanica River recharge area. Inset shows the radar distribution of rainfall above Slovenia and the Ljubljanica River recharge area on $25^{\text {th }}$ August 2018 (ARSO, 2020a). Elevation data have been obtained from ARSO (2020b). 
Veliko Brezno v Grudnovi Dolini (H1), with an initial increase of $33 \mathrm{~m}$ in only 6 hours (August $26^{\text {th }}$ at $4: 00$ ). The logger position in Andrejevo Brezno 1 (H2) is above the water level at low and medium flow conditions. The hydrograph shows peak of high floods and is delayed and less abrupt. The peak level in $\mathrm{H} 2$ was recorded on the August $27^{\text {th }}$ at $0: 00$. The reaction in $\mathrm{H} 1$ was simultaneous to the increase of discharge at the springs of the Ljubljanica River (Fig. 2). This indicates a fast response of the system to the high quantity of rain that infiltrated through the unsaturated zone.

Records from Gradišnica (W2) and Gašpinova Jama (W3) show almost identical response of the water level with a maximum increase of $14 \mathrm{~m}$ on August $26^{\text {th }}$ at 6:00. The relatively strong response at W2 and W3 in the absence of flow Planinsko Polje supports our previous assumption on flow connection between the eastern border of Hrušica Plateau (H1) and the Logatec region (W2/W3).

Level hydrographs in W2/W3 correlate with that in
H1, showing same peaks and inflections with an up to $2 \mathrm{~h}$ delays. The level responses fit well into the concept presented in original paper of Blatnik et al. (2019). This assumes a flow restriction downwards from W2/W3, which keeps the uniform level in the W2/W3 region and another restriction between $\mathrm{H} 1$ and $\mathrm{W} 2$, which causes the backflooding of the $\mathrm{H} 1$ region.

Blatnik et al. (2019) demonstrated that water originating from the Hrušica Plateau periodically flows towards the estavelles near Grčarevec and consequently recharge Planinsko Polje during the onset of high-water periods. Similarly, the same estavelles behave like ponors and drain water back into the aquifer when the flood is receding in the polje. This assumption was proved by analysing both water level and temperature dynamics in the cave Andrejevo Brezno 1 (H2) and in Planinsko Polje (Blatnik et al. 2019). During August 2018 event, the water level in Andrejevo Brezno 1 (H2) barely reached the level of polje, so that the estavelles were not activated.

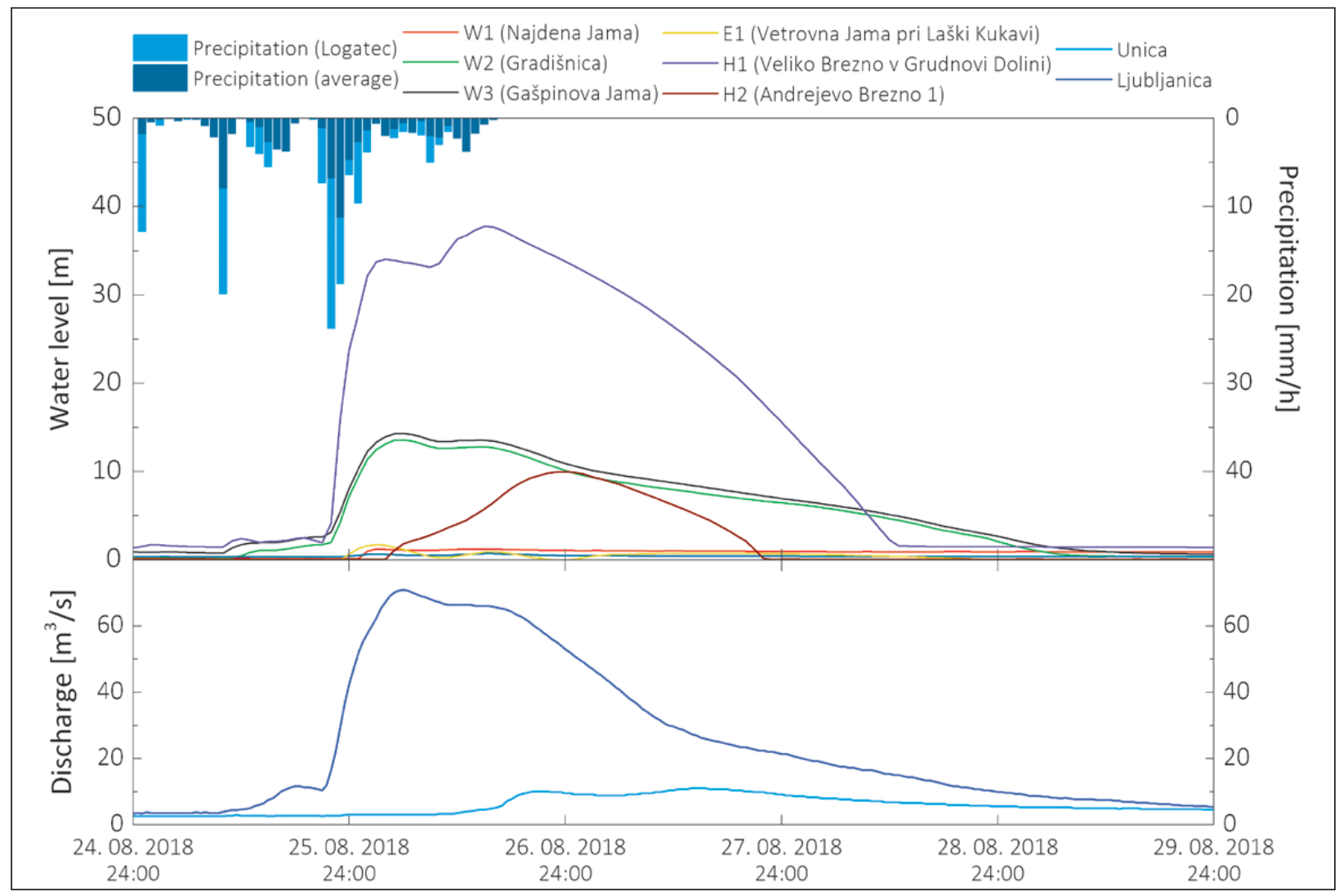

Fig. 2: Hydrological data of the event of August 2018 showing precipitations, increase of water level and flow discharges in selected caves and rivers after the intense rainfall event of August 2018. Average precipitation depicts the mean hourly precipitation of the entire Ljubljanica River recharge area, computed based on data coming from 9 rain gauges installed in the catchment. Discharge data were provided by ARSO (2020c). 


\section{CONCLUSIONS}

The data of the August 2018 event give further evidences to the concepts presented by Blatnik et al. (2019) on the flow connection between the border of Hrušica Plateau and the Logatec region. This implies a zone of high hydraulic transmissivity within the Idrija Fault Zone, which is otherwise acting as a regional flow barrier. The data also demonstrate that this flow may present an important contribution of the total outflow at the springs of Ljubljanica region.

Last but not least, only long term observations can capture variety of hydrological events and responses, which are necessary to build reliable conceptual models of aquifer's structure and functioning.

\section{ACKNOWLEDGEMENTS}

This notice has been done within the framework of several research projects funded by the Slovenian Research Agency (ARRS). The work of M.B. was supported by the Young Researchers Programme of the Slovenian Research Agency (ARRS). The work of F.G. was supported by the Slovenian Research Agency (ARRS) under grants J5-7178 Integral system of flood sustainable spatial planning and J2-7322 Modelling hydrologic response of non- homogeneous catchments and programme P6-0119. The work of C.M. was supported by the Slovenian Research Agency (ARRS) under grant L1-7555 Development and application of method for quantity and quality assessment of ground water resources in karst. The Slovenian Environment Agency (ARSO) is thanked for providing DEM, meteorological and discharge data registered by its measurement network.

\section{REFERENCES:}

ARSO, 2020a: Meteorological archive.- [Online] Available from: http://meteo.arso.gov.si/met/sl/archive/ [Accessed June 30 ${ }^{\text {th }}$ 2020].

ARSO, 2020b: Lidar data fishnet.- [Online] Available from: http://gis.arso.gov.si/ [Accessed June 30 2020].

ARSO, 2020c: Hydrological archive.- [Online] Available from: http://vode.arso.gov.si/hidarhiv/ [Accessed June $30^{\text {th }} 2020$ ].
Blatnik, M., Frantar, P., Kosec, D. \& F. Gabrovšek, 2017: Measurements of the outflow along the eastern border of Planinsko Polje, Slovenia.- Acta Carsologica, 46, 1, 83-93. DOI: 10.3986/ac.v46i1.4774

Blatnik, M., Mayaud, C. \& F. Gabrovšek, 2019: Groundwater dynamics between Planinsko Polje and springs of the Ljubljanica River, Slovenia.- Acta Carsologica, 48, 2, 199-226. DOI: 10.3986/ac.v48i2.7263

\section{POVZETEK}

Članek »Dinamika podzemne vode med Planinskim poljem in izviri Ljubljanice, Slovenija «, ki je bil objavljen v Acta Carsologica 48/2, se je v osnovi osredotočil na raziskave pretakanja podzemne vode med Planinskim poljem in izviri Ljubljanice. Med rezultati so bila izpostavljena tudi nova dognanja o smereh pretakanja podzemne vode, ki so bila ugotovljena na podlagi zveznih meritev vodostajev, temperature in specifične električne prevodnosti vode ter testiranja $\mathrm{z}$ numeričnimi hidravličnimi modeli.
Med drugim je bila ugotovljena domnevna smer pretakanja vode iz jam Veliko brezno v Grudnovi dolini (H1) in Andrejevega brezna 1 (H2), ki se nahajata na vzhodnem pobočju planote Hrušica. Od tu naj bi se voda v času visokih vodostajev pretakala $\mathrm{v}$ več smeri, in sicer proti estavelam pri Grčarevcu (SZ rob Planinskega polja) ter proti območju Logaškega ravnika, kjer se nahajata jami Gradišnica (W2) in Gašpinova jama (W3). Pričujoč dodatek k članku potrjuje pretekle domneve, v njej pa opisu- 
jemo manj običajen padavinski dogodek iz konca avgusta 2018, ko je na območju Hrušice padla mnogo večja količina padavin kot v preostalem delu porečja Ljubljanice. Rezultat je bil rahlo povišan pretok Unice, pri katerem je voda dosegla le vzhodno skupino požiralnikov na Planinskem polju. Posledično so se vodostaji v nekaterih dolvodno ležečih jamah Vetrovna jama pri Laški kukavi (E2) in Najdena jama (W1) zelo malo povišali $(<2 \mathrm{~m})$. Mnogo bolj izrazit in zelo hiter je bil dvig vodostaja $\mathrm{v}$ jamah na pobočju Hrušice (do $37 \mathrm{~m} \mathrm{v} \mathrm{H1).} \mathrm{Porast} \mathrm{vodostaja} \mathrm{v} \mathrm{ja-}$ mah Gradišnica (W2) in Gašpinova jama (W3) je bil znaten $(14 \mathrm{~m})$, prav tako je do odziva in viška prišlo le malo po porastu v Velikem breznu v Grudnovi dolini (H1). Ob teh predpostavkah in dejstvu, da je bil dotok iz Planinskega polja zelo skromen, je hidrološka povezava med planoto Hrušico na eni strani Idrijske prelomne cone in območjem z Gradišnico (W2) in Gašpinovo jamo (W3) na drugi strani nedvoumna. Meritve s tem podkrepijo tudi domneve, da se na proučevanem območju nahajajo zožitve in različno prevodna območja Idrijske prelomne cone, ki vplivajo na zelo sinhrono dinamiko vodostajev. Proučevan padavinski dogodek je nakazal tudi, da je dotok iz območja Hrušice lahko zelo izdaten, saj se je najvišji pretok Ljubljanice $\left(\sim 71 \mathrm{~m}^{3} / \mathrm{s}\right)$ izrazito presegel tistega na Unici $\left(11 \mathrm{~m}^{3} / \mathrm{s}\right)$. Pričujoč dodatek $\mathrm{k}$ članku torej potrjuje domneve $\mathrm{v}$ predhodno opisanem članku, hkrati pa tudi poudarja pomen dolgoročnih meritev $\mathrm{v}$ kraških vodonosnikih, ki v množici medsebojno podobnih zabeležijo tudi nekatere manj običajne, a za interpretacije zelo pomembne dogodke. 